\title{
Georgian Teachers' Awareness of the Importance of Student-centered Classroom Management Tendencies
}

\author{
Nino Tvaltchrelidze $e^{1} \&$ Nana Aleksidze ${ }^{2}$ \\ ${ }^{1 \& 2}$ International Black Sea University, Tbilisi, Georgia \\ Correspondence: Nino Tvaltchrelidze, International Black Sea University, Tbilisi, Georgia. \\ Email: ntvalchrelidze@ibsu.edu.ge
}

Received: January 15, $2019 \quad$ Accepted: February 20, $2019 \quad$ Online Published: March 1, 2019

doi: 10.23918/ijsses.v5i3p207

\begin{abstract}
: 21-st century teachers of high school are elaborating those needed approaches in education and in classroom management which not only serve good teaching but also serve the moral values and the basic skills for the development of people and societies, which have to be shaped in a decisive manner during adolescence and youth. Further to this stage, it is possible, and of course imperative, to boost practical skills, to widen knowledge and to develop virtues. Education plays crucial role in the formation of the society. It is a powerful tool to empower children and adult learners to become active participants in the process of development and transformation of their societies. Georgia is a developing country with 25 years of democracy. This country is characterized with national, cultural, religious and ethnical pluralism. These factors put great challenges towards the country and its educational system and of course towards school teachers. Teachers for maintaining effective classroom activities and creating productive lessons need not only to be good teachers and good at teaching but also to be transformative leaders and lead their students to acquire all the needed skills for being active and decent members of the country's society.
\end{abstract}

Keywords: Student-Centered Teaching, Classroom Management, High School Education

\section{Introduction}

Accelerated development of the contemporary era brought many obstacles and challenges towards the world society. The new world educators began thinking about the secret of educating young people and teenagers in order to make their participation under the equal conditions in sustainable development, to manage and design the educational process and upbringing to be able to overcome the limits of the old models, to prepare youngsters for the new world challenges and for those novelties which the $21^{\text {st }}$ century is characterized by. As Mr. Koichiro (1960), the Director-General of UNECSO states, contemporary teachers and people in the educational field try to find right way among educational approaches and prepare young people "to face challenges of the globalized world with a human face" and to use every decent and possible opportunity for that purpose (UNESCO,1960). Education is a primary need in this era of globalization. Education not only gives insight, but also grooms the personality, sophisticates moral values, adds knowledge and gives skills.

\section{Problem Statement}

Education plays crucial role in the formation of the society. It is a powerful tool to empower children and adult learners to become active participants in the process of development and transformation of their 
societies. Learning should also focus on values, attitudes and behaviors which enable individuals to learn and live together in a world characterized by diversity and pluralism.

Georgia is a developing country with 25 years of democracy. This country is characterized with national, cultural, religious and ethnical pluralism. These factors put great challenges towards the country and its educational system and of course towards school teachers. Teachers, for maintaining effective classroom activities and creating productive lessons, need not only to be good teachers but also to be transformative leaders and lead their students to acquire all the needed skills for being active and decent members of the country's society.

The focus of the contemporary education needs to be made on the students and the environment; to encourage learners to feel the reality and to maintain real life activities, to understand their active role and important responsibility in their learning, to be motivated, to motivate others and to strive for the constant process of self-actualization. In order to overcome those challenges and succeed in interesting but difficult educational process there are some factors which bear high significance:

- $\quad$ Choosing the right way and approaches for achieving the needed result.

- $\quad$ Being goal oriented but focused on the learners' meaningful learning.

- $\quad$ Rising teachers' self-awareness of their self-actualization and professional development.

- $\quad$ Rising students' awareness of their self-actualization and future realization.

- $\quad$ Collaboratively building effective student-oriented team and organize student-centered classroom management.

\section{The Goal of the Research}

The conducted research serves to find out the Georgian teachers' awareness in the student-centered classroom management and to detect the real classroom life in Georgian high schools from the perspective of several factors:

- $\quad$ To prove the need of adapting relevant educational approaches in Georgian high schools.

- To raise teacher awareness of the significance of student-centered classroom management in self-actualization process of learners.

- $\quad$ To detect and analyze the challenges of the educational process in Georgian high schools.

- $\quad$ To plan and organize required steps for the appropriate research through the relevant research methods and methodology.

- $\quad$ To collect data, analyze and make relevant conclusions and fruitful recommendations.

The study will discover the existing reality of the Georgian high schools, private and public ones in the big cities as well as in the regions. The goal of the current research is to examine the rate of studentcentered tendencies in Georgian high school classrooms and teachers' awareness and attitudes towards the student-centered teaching and learning. The study will make it clear whether the student-centered approach is really a means of Georgian teachers' self-actualization to raise their perception of being a self-actualized student-oriented teacher. 


\section{Research Questions}

The research questions are based on the problems and challenges of the topic under the research. Teachers need to be well prepared, experienced, well adjusted, motivated and equipped with all the needed skills and knowledge to meet the challenges of the contemporary educational demands, face the problems of the educational process carefully and professionally, organize and maintain classroom management issues for raising student-centered tendencies with students and in the whole educational process. The planned study serves to detect existing educational situation in Georgian high schools and find relevant means to answer the challenging questions referring the student-centered classroom management tendencies and self-actualization:

- $\quad$ Are Georgian high schools led by the student-centered classroom management principles?

- What is the Georgian high school teachers' perception towards the educational process they lead and how can they evaluate the student-centered tendencies in their classrooms?

- What should be done to make the process more effective and classrooms more student-oriented?

- What should be done to raise and enhance Georgian high school teachers self-awareness in the student-centered tendencies for their and the students' self-actualization?

- What predictions and prognosis can be done on the bases of the conducted research and what actions are to be done in this regard?

\section{Literature Review}

In order to maintain student-centered tendencies in their teaching, instructors are to seek different educational and behavioral approaches and fix and tailor them to maintain their effective application. Cooperative Discipline Program and Consistency Management is considered to be one of the means to elaborate students needed skills to feel satisfied in the student-centered classroom climate. Being cooperative, communicative, able to work with groups and in teams, having relevant peer assessing ability and self-organization are those skills which are maintained through the Cooperative Discipline Program and Consistency Management. According to the CMDC and Albert's Cooperative Discipline Programs, collaborative and cooperative learning are the key aspects of student-centered approach. Student-centered teachers within the Cooperative Discipline Program framework always aid students to have active interactions with the mates, facilitate students' responsible role in the process and actualize them to be risk takers and initiative (Albert, 1996). Collaborative learning encourages students to be more assisting and caring for the group and class mates. It encourages the deep interaction among the students and between them and the teachers. Students within the Cooperative Discipline Program elaborate the interpersonal and communicative skills, techniques for understanding, caring and respecting each other, preventing dispute and disagreement. Students within this program are positively independent (Jacobs, 2015).

Contemporary classrooms are provided with more ethnically, culturally, racially diverse students, which place significant challenges to all the people in the field of education: teachers, government, principles and parents. All of them need the certain skills to handle these challenges and get success. Teacher's role in adopting and maintaining approach of Culturally Responsive Teaching (CRT) is higher, because he/she is the person in the classroom who guides the whole process. The teacher's role is higher when 
the teaching is student-centered and oriented to the learners' demands and their learning goals. Students will never be self-actualized if they experience some kind of inhibition and restriction. Being culturally responsive teacher means creating acceptable and effective classroom environment, managing process within the scope of student-centered conditions and getting the positive learning outcomes for their future self-actualization. Effective student-centered education and classroom management places concrete demands not only to the teachers but also towards the educators, counselors, psychologists and administrators. This demand requires from them to get prepared and be knowledgeable to create and maintain productive and positive management oriented for getting effective outcome (Allison \& Rehm, 2007).

\section{Humanistic Conception in Education}

The most persuasive exploration of a humanistic orientation to learning came from Carl Rogers (1969) and Abraham, H. Maslow (1970). Their theories are devoted toward applying the results of their psychological researches on the person-centered teaching where empathy, caring about students and genuineness on the part of the learning facilitator were found to be the key traits of the most effective teachers. Rogers (1969) suggests the following elements for being involved in significant and meaningful process of learning:

- $\quad$ Personal involvement: the whole person in both feeling and cognitive aspects being in the learning event.

- Self-initiation: even when the impetus or stimulus comes from the outside, the sense of comprehending it comes from within.

- $\quad$ Evaluation by the learner: when the learners know what they really want to know and feel that the teaching meets their needs and is meaningful.

- $\quad$ Essence is meaning: when such learning takes place, the element of meaning to the learner is built into the whole experience.

According to Rogers (1969) one of the significant factors in maintaining productive student-centered teaching is to develop those core characteristics with students which foster their self-growth and selfactualization. These characteristics help students to be self-actualized and "fully functioning" individuals with the developed personalities.

Rogers listed the characteristics of a "fully functioning" person:

1. Freedom of choice: not being shackled by the restrictions that influence an incongruent individual, they are able to make a wider range of choices more fluently. They believe that they play a role in determining their own behavior and so feel responsible for their own behavior.

2. Creativity: it follows that they will feel freer to be creative. They will also be more creative in the way they adapt to their own circumstances without feeling a need to conform.

3. Reliability and constructiveness: they can be trusted to act constructively. An individual who is open to all their needs will be able to maintain a balance between them. 
Humanistic teachers believe it is important for students to be motivated and engaged in the material they are learning, and this happens when the topics are something the students need and want to know. The humanistic approach places a great deal of emphasis on students' choice and control over the course of their education. Humanistic education is oriented on the person, on the students and is called personcentric education. Contemporary teaching is more oriented to adopt that kind of education and call this student-centered approach. Within student-centered teaching and learning pupils can get answers to the questions:

- What are their rights and responsibilities towards the society?

- How can they protect their and others' fundamental rights?

- How can they ensure harmony and peace in their society?

- How can they achieve the condition of self- realization?

Student-centered learning can, thus, be seen as a form of self-actualization, it contributes to psychological health of the students and creates psychologically safe climate in the classroom. Yet while self-actualization may be seen as the primary goal, other goals linked to the main purpose of students' self-actualization are also around.

Humanistic educators believe that both feelings and knowledge are important to the learning process. It is believed that the overall mood and feeling of the students can either hinder or foster the process of learning. Unlike traditional educators, humanistic teachers do not separate the cognitive (thinking) and affective (emotional) domains. These domains form students' skills of critical thinking, problemsolving, practical abilities, value creation, communication, motivation and perceptions.

Effective, self-actualized teachers can significantly enhance student learning. Humanistic approach places teacher as a facilitator who enables students to be active and elicits their knowledge and inner potential to the right direction for their self-actualization. Good student-centered teachers while facilitating their students' learning should provide several factors (Rogers, 1969):

1. Response to student feeling

2. Use of student ideas in ongoing instructional interactions

3. Discussion with students (dialogue)

4. $\quad$ Praise of students

5. Congruent teacher talk (more relevant and much less ritualistic)

6. Tailoring of contents to the individual student's frame of reference (explanations created to fit the immediate needs of the learners)

7. Smiling with students

\section{Research Findings and Analyses}

The current research applies following research methodology: primary and secondary data collection and quantitative research methods. In order to maintain all the above mentioned steps and elaborate those needed actions for the main purpose of the research the chosen research methodology will make 
the whole research to be more systematic, organized and profound for making fruitful analyses. The collected findings will make it clear what is the reality in today's Georgian high schools and what is desirable or necessary to be done.

The quantitative research is based on the questionnaire, with 30 questions of multiple answers measuring the student-centered and self-actualization rate and tendencies of Georgian high school teachers. The questions measure five important factors of student-centered education in 6 important aspects. The five key points (Weimer, 1988) are the following:

1. Classroom environment

2. Course material review

3. Instructor's actualization rate

4. General motivation and self-reflection of the student and the teacher

5. Specifically what needs improvement

They are measured in six aspects:

1. Balance of power

2. Function of content

3. Role of the teacher

4. Responsibility of learning

5. Purpose and processes of evaluation

6. Self-actualization

The research was conducted in eight schools of Georgia in order to get the relevant findings and results. The schools were from different regions of Georgia: two schools from Tbilisi (the capital city of Georgia, the eastern part), two schools from Batumi (the western part of Georgia), three schools from eastern region of the country and one school from the village (southern part of Georgia). Officially there are 2321 authorized schools in Georgia both public and private. The current research is oriented to detect and analyze the gathered data from participant schools and to compare the tendencies of the research objectives in schools from big cities and regions. The research population of the current study are twenty-six high school teachers from all the above mentioned schools in Georgia.

The results of the questionnaire are measured on the bases of the principles of the Likert Scale. According to Bright Hub Education (2018), Likert Scale is used very frequently in educational and special educational researches. The answers were pointing either agreement or disagreement, frequency of the facts denoted in questions.

The offered rubrics of the questionnaire measure the following four important tendencies of the research:

- $\quad$ Student-centeredness means the power is shared and the learning is meaningful.

- $\quad$ Teacher-centeredness the power is not shared and the learning is old-habited.

- No balance means there is no indicator of balance sharing and the learning in not meaningful at all. 
- $\quad$ Neutral not decided.

Table 1 indicates teachers' responses from the capital city.

Table 1: Research findings from Tbilisi high school teachers' responses

\begin{tabular}{|c|l|l|l|l|l|l|}
\hline$\#$ & & $\begin{array}{l}\text { Student- } \\
\text { centered }\end{array}$ & $\begin{array}{l}\text { Teacher- } \\
\text { centered }\end{array}$ & $\begin{array}{l}\text { Not } \\
\text { decided }\end{array}$ & No Balance & total \\
\hline 1 & $\%$ & $71.5 \%$ & $28 \%$ & 0 & $0.5 \%$ & $100 \%$ \\
\hline
\end{tabular}

As we see from the results shown in the Table 1, almost $72 \%$ of teachers consider themselves as student-centered and their classroom student-oriented. The percentage $(28 \%)$ of the teacher-centeredness compared to the results in student-centeredness $(71.5 \%)$ is quite low. No balance gained $0.5 \%$ of answers. Although the responses from the teachers of the capital city are quite hopeful with regard to having more student-centered instructions than teacher-centered ones, still $28 \%$ of teacher-centered responses are very important to mention and to take into consideration, as this is almost one thirds of the total amount. According to the Table 1, the response type Not Decided gained $0 \%$ which means that teachers are aware of their classroom conditions and situation and no one has dubious and ambiguous attitude towards their classroom life and their students learning.

Table 2 indicates the findings from the other regions of the country except the capital city.

Table 2: Research findings of teachers' responses from other regions of Georgia

\begin{tabular}{|c|l|l|l|l|l|l|}
\hline$\#$ & & $\begin{array}{l}\text { Student- } \\
\text { centered }\end{array}$ & $\begin{array}{l}\text { Teacher- } \\
\text { centered }\end{array}$ & $\begin{array}{l}\text { Not } \\
\text { decided }\end{array}$ & No Balance & total \\
\hline 1 & $\%$ & $66 \%$ & $33.5 \%$ & 0 & $0.5 \%$ & $100 \%$ \\
\hline
\end{tabular}

According to the findings of Table 2, teachers from the regions are and tend to be more student-centered than teacher-centered or having no balance at all. $66 \%$ is more than half of the total number of the respondent teachers who seem to be student-centered $33.5 \%$ of teachers still remain teacher-centered and 0.5 of the respondent instructors think that there is no balance in their classrooms at all. As for being neutral and having no answer, we don't have such kind of teachers in the survey according to the Table 2 .

Table 3 indicates the overall results from the total twenty-six participant teachers throughout the country.

Table 3: Research findings from all teachers throughout the country

\begin{tabular}{|l|l|l|l|l|l|l|}
\hline$\#$ & & $\begin{array}{l}\text { Student- } \\
\text { centered }\end{array}$ & $\begin{array}{l}\text { Teacher- } \\
\text { centered }\end{array}$ & $\begin{array}{l}\text { Not } \\
\text { decided }\end{array}$ & No Balance & total \\
\hline 1 & $\%$ & $70 \%$ & $26 \%$ & 0 & $4 \%$ & $100 \%$ \\
\hline
\end{tabular}

Table 3 shows the general situation in Georgian schools (according to the findings got from the participant schools). $70 \%$ of the respondent teachers form the capital city and from the regions have more student-centered tendencies developed in their classroom and are more student-oriented instructors. $26 \%$ of the teachers continue their classroom management with teacher-centered tendencies. It turned 
out that $4 \%$ of instructors have not clearly defined approach and therefore have no balance. None of the teachers consider themselves to be neutral and having no answer at all.

Table 4: Indicates the results from capital city and other regions of the country

\begin{tabular}{|c|l|l|l|l|l|l|l|l|l|l|}
\hline Category & \multicolumn{2}{|c|}{$\begin{array}{l}\text { Student } \\
\text { centered }\end{array}$} & \multicolumn{2}{c|}{$\begin{array}{l}\text { Teacher } \\
\text { centered }\end{array}$} & \multicolumn{2}{c|}{ Neutral } & \multicolumn{2}{c|}{ No Balance } & \multicolumn{2}{c|}{ Total } \\
\hline Location & $\begin{array}{l}\text { Capital } \\
\text { city }\end{array}$ & $\begin{array}{l}\text { Other } \\
\text { regions }\end{array}$ & $\begin{array}{l}\text { Capital } \\
\text { City }\end{array}$ & $\begin{array}{l}\text { Other } \\
\text { regions }\end{array}$ & $\begin{array}{l}\text { Capital } \\
\text { City }\end{array}$ & $\begin{array}{l}\text { Other } \\
\text { regions }\end{array}$ & $\begin{array}{l}\text { Capital } \\
\text { City }\end{array}$ & $\begin{array}{l}\text { Other } \\
\text { regions }\end{array}$ & $\begin{array}{l}\text { Capital } \\
\text { City }\end{array}$ & $\begin{array}{l}\text { Other } \\
\text { regions }\end{array}$ \\
\hline $\begin{array}{c}\text { Result } \\
\%\end{array}$ & 71.5 & 70 & 28 & 26 & 0 & 0 & 0.5 & 4 & 100 & 100 \\
\hline
\end{tabular}

According to the results we can consider that teachers tendencies about their teaching and about the general trends in their classrooms do not differ much comparing results from the capital city and from the regions. $71.5 \%$ of teachers from the capital city and $70 \%$ of teachers from the other regions of the country are found to be student-centered. As for the teacher-centered tendencies $28 \%$ goes for high school teachers in the capital city and $26 \%$ for the teachers form other regions. In this case the notable fact is, that teachers from the capital city are more teacher-centered (by 2\%) than the teachers from the regions. None of the participant school teachers were neutral and none of them indicated that they cannot decide the exact answer. As for the No Balance factor, here capital city teachers' answers gained very little percentage $0.5 \%$ but $4 \%$ of the teachers from the other regions admitted that they have no balance in their classrooms. In this case we can consider that teachers from the regions have more imbalanced classroom management than teachers from Tbilisi (the capital of Georgia).

\section{Conclusion}

According to the research questions and the research findings the current situation in Georgian schools give bases to conclude that:

- Georgian high schools bear more student-centered tendencies than teacher-centered, though not completely. Georgian schools still need to be more oriented towards adopting the studentcentered classroom management approach, as according to the research findings we cannot definitely conclude that Georgian high schools are completely led by the student-centered tendencies.

- Majority of the Georgian teacher consider themselves to be student-centered, but their selfreflection is still not quite defined, as one thirds of the respondent teachers do not have well defined self-refection and consider themselves to be teacher-centered or having no balance.

- $\quad$ Data collected from the surveys make it possible to conclude that Georgian teachers are really oriented to be student-centered, but they still lack self-actualization to be completely studentoriented instructors. In this case there are steps to be carefully organized and maintained to the intensification of the Georgian teachers' self-actualization process for motivating them to become fully student-centered. 
Based on the results and obtained findings there are some recommendations for the instructors to make their students more self-actualized and classroom more student-centered. Instructors should constantly be oriented to:

- $\quad$ Identify students' needs

- $\quad$ Be responsive to the students' feelings and emotions

- $\quad$ Make students engaged in the ongoing processes of the classroom life

- $\quad$ Give students freedom of their choice and make them understand their role in the classroom life

- $\quad$ Encourage students to plan, organize and forecast future steps within the classroom management frames

- Have active communication with students, maintaining classroom hours and discussions in or out of the classroom

- $\quad$ Give feedback and praise the students for their behavior or achievements

- $\quad$ Empower students be self-confident

- $\quad$ Be like friend and like mentor

- $\quad$ Be flexible and innovative

As Weimer (2002) states, student-centered principles and all the related instructions are the whole bundle of those relocated powers which exist in the everyday life of the classroom, this relocation and balance of the power make students be under some but not full control, motivate them to take charge in the learning process which is not beyond the classroom and the learners but within them and really effects them. In other cases, when the learning or the whole educational process is teacher-center and centralized, this decentralizes the students' interests towards the learning. One of the major purpose of student-centered approach is known to be personal growth, self-actualization, self-directed and selfregulated learning. The process toward this purpose is transformation, shifting from teacher-centeredness into the student-centered one. Teachers act like effective managers who master all the needed skills of teaching and motivating students to be active and actualized learners.

\section{References}

Albert, L. (1996). Cooperative discipline. Circle Pines, MN: American Guidance Service, Inc.

Allison, N., \& Rehm, M. (2007). Effective teaching strategies for middle school learners in multicultural, multilingual classrooms. Middle School Journal, 39(2), 12-18.

Jacobs, G. M. (2015). Collaborative Learning or Cooperative Learning, Beyond Words. Widya Mandala Catholic University. Vol.3, No.1. Retrieved 2018 autumn from www.georgejacobs.net

Maslow, A. H. (1970). Motivation and personality. Reprinted from the English Edition by Harper \& Row, Publishers.

Mayflor, M. (n.d). Brighthub.Edu. The Likert Scale Format and Sample Types of Questions. Special Ed Information for Teachers and for Parents. Received 2019. January from https://www.brighthubeducation.com/special-ed-law/13507-likert-scale-questionnaire-formatand-sample-questions.

Rogers, C. (1969). Freedom to learn. Columbus, Ohio: Charles E. Merrill.

UNESCO 1960 Convention, http://www.unesco.org/new/en/social-and-human-sciences/themes/fightagainst-discrimination/role-of-education/

Weimer, M. (1988). How am I teaching? Madison, WI: Magna publication Inc.

Weimer, M. (2002). Lerner centered teaching. San Francisco: John Wiley \& Sons, Inc. 